usual low-speed engine. Mr. Ricardo suggests that piston design in particular is looked on from such different angles by the two schools as to lead to very marked differences in engine types. A heavy piston means high inertia forces at the beginning and end of each stroke; this means a stout connecting-rod; both these in turn call for a strong and heavy crank requiring massive bearings, and at once we are led to the ordinary gasengine of pre-war days. The aero-engine has developed a piston suitable for heary loads and high speeds. It is surely unlikely that designers of other types of internal-combustion engine will fail to draw the obvious conclusion.

The war may be expected to leare its mark on internal-combustion engine design in two ways: first, by greatly lightening the motor-car engine, so that its weight per horse-power may not compare so unfavourably with that of aero-engines; and secondly, by making the slow-speed stationary, or nearly stationary, gas- or oil-engine a much less cumbrous machine.

Evolution in engine practice has long been towards ever-increasing speeds. The old beamengines of the early part of last century gave place to an engine of much higher speed with hundreds, instead of tens, of revolutions per minute. The higher speed meant, for equal horse-power, less total force on the piston, hence a less diameter of piston, a smaller and lighter engine. Now again we find this same evolutionary process at workpiston speeds are rising and the weight per horsepower ratio grows less.

In view of the specially intense interest which the agricultural industry will have for humanity during the next term of years, it is important to consider how far our recent increase in knowledge of the potentialities of the internal-combustion engine may be harnessed to this work. Ford in America has done much-but mainly on what may be termed pre-war data. Much remains to be done in this coming post-war period. High piston speeds, light reciprocating parts, and the use of high-grade steels should, combined, produce an agricultural machine as efficient for its purpose as the motor-car and aeroplane have become. The annual output of high-speed internal-combustion engines in this country is at present at the rate of some Io, 000,000 h.p. annually. A large part of this has been for air work; a smaller fraction will suffice now. Here is to be found a great opportunity for the internal-combustion engine in fresh enterprise in new fields.

H. E. W.

\section{NURSING HABITS OF ANTS AND TERMITES.}

A

RECENT paper by Mr. W. M. Wheeler, in the Proceedings of the American Philosophical Society, Philadelphia, gives some interesting details of the behaviour of certain ants in the care of their offspring. The larvæ of the primitive subfamily Ponerinæ are fed, not, as in the case of the most highly specialised ants, with food regurgitated by the workers, but with fragments of insects. Speaking of a species of this NO. 2564 , VOL. IO2] subfamily common in central Texas, Mr. Wheeler says :-

These larvæ are placed by the ants on their broad backs, and their heads and necks are folded over on to the concave ventral surface, which serves as a table or trough on which the food is placed by the workers.

In the case of another species, as soon as the food is in place it is sometimes covered by the larva with a copious discharge of a secretion containing a proteolytic ferment, by means of which the food undergoes extra-intestinal digestion. Mr. Wheeler adds the curious observation that this liquid is eagerly lapped up by the nurses.

The larvæ of four species of ants belonging to the subfamily Myrmecinæ were collected by Mr. Lang in the Belgian Congo. In three of these, remarkable exudatory appendages exist, some of which consist of a basal enlargement filled with fat-cells, and a slender, tubular distal portion containing a granular liquid which the author thinks can only be interpreted as an exudate derived from the fat-cells, and capable of being filtered through the cuticula of the appendages by means of the pressure exerted by an elaborate system of muscles. That the chitinous envelope of these structures is not necessarily impervious to the passage of a secretion is shown by the researches of Holmgren, Biedermann, Kapsov, Casper, and others. From the ontogenetic and phylogenetic history of these appendages, and especially from the fact that they appear to be developed in inverse ratio to the salivary glands used in extra-intestinal digestion, Mr. Wheeler concludes that their secretion, like that of the salivary glands in the Ponerinæ, is capable of furnishing nutriment to the nurses, the benefit of the feeding habit being therefore reciprocal. This conclusion he considers to be supported by the observations of Wasmann on the Staphylinid beetle Xenogaster inflata, which inhabits the nests of termites. In this larva the fat-body produces an exudation which, after passing through a layer of hypodermis, reaches the surface through the cuticle. Similar phenomena are present in other beetles and Hymenoptera which frequent the nests of ants or termites, as recorded by Trägårdh; while Holmgren has found that, quite apart from their guests, termites feed to a large extent on the exudation furnished in different degrees by the several castes of their own species.

For this reciprocal feeding, whether within or without the limits of the same species, Mr. Wheeler proposes the term "trophallaxis." The practice has, he considers, an important bearing on the substitution of the social for the solitary habit in various species of Hymenoptera. The various trophallactic relations existing in communities of ants are grouped by him as follows: (I) Trophallaxis between mother or adult worker and larval brood; (2) between adult ants (mutual regurgitation); (3) between ants and true guests ; $(4)$ between ants of different species. Besides these reciprocal relations there is the ordinary trophic connection between ants and other insects outside the nest (as aphides and certain Lepidopterous larvæ), and 
also between ants and various plants known as Myrmecophytes.

The author takes occasion to combat Wasmann's view as to a special symphilic instinct in ants and termites. The latter observer adduces certain ascertained facts regarding Lomechusa strumosa, a beetle parasitic in the colonies of Formica sanguinea. The adult beetles are fed and licked by the ants, but the beetle larvæ devour the larvæ of their hosts; moreover, in some colonies the presence of the parasite leads to the development of pseudogynes-i.e. forms intermediate between workers and females, which are incapable of performing the functions of either caste. The infection of an ant colony by Lomechusa is therefore presumably detrimental to the hosts. This is admitted by Wasmann, who nevertheless contends that Formica sanguinea has acquired a special symphilic instinct, not under the influence of natural selection, but in connection with the use of a process analogous to artificial selection as practised by man. Mr. Wheeler holds, on the other hand, that the beetle is the aggressor, and that the fact that it is licked and tended by the ants is a mere incidental result of the nursing habits of the latter with regard to their own offspring.

F. A. D.

\section{PHYSICS IN SCHOOLS.1}

$\mathrm{N}$ opening the discussion described in the report before us, Prof C. H. Lees, president of the Physical Society, stated that the meeting was the outcome of the desire of the society to help those engaged in science teaching in public and secondary schools to carry out the extension of their work which will probably ensue in the course of the next few years. We may begin our notice of the report by congratulating those responsible for the idea of such a meeting and those to whom the credit of its skilful organisation belongs.

Sir Oliver Lodge opened with a characteristically direct remark:- "Mr. President, I very much agree that it is desirable that the average man should know more physics than he does at present. He could hardly know less." But the speaker did not pursue the delicate question as to the responsibility for this state of things, whether the average man or the teacher of physics is to blame. Nor need we inquire, since the one clear, unmistakable inference from the discussion as a whole was that teachers of physics are tackling with much thoughtful energy the problem of providing courses of physics which will suit those who will get in schools the only knowledge of physics they are ever likely to possess.

It is worth noting that Sir Oliver Lodge considers it best to begin with the biological sciences, for cultivating the faculty of observation. Why this should be so was not explained; nor was anything said as to how the power of observing gained in natural history studies was to be transferred to the field of physics. Here we touch on the

1 "The Teacbing of Physics in Schools." Report of a discussion at a meeting of the Physical Society, June 14,7973 . Pp. 43. (London: FleetwayF'ress, rgr 8.) Price $r s .2 d$. post free.

NO. 2564 , VOL. IO2] weak side of the discussion-there was too insecure a basis of psychological knowledge, too little recognition of the imperative primary need to find out how the boy's mind will work with spontaneity as well as under discipline.

There are several clear statements in this report on the distinction between physics for the boy who will specialise in science and "Physics for All," the contribution of Prof. R. A. Gregory being particularly clear and weighty. The need for inspiring courses was well emphasised by both the opening speakers; the Harrow syllabus submitted by Mr. C. L. Bryant was an able effort to meet this need.

Every schoolmaster feels one great difficulty in carrying out his ideals, viz. the narrow limits of time within which his work has to be carried out. Dr. T. J. Baker brought this point clearly before the society, and from this point of view criticised the recommendation of Sir J. J. Thomson's Committee to lower the school-leaving age from nineteen to eighteen. Probably the majority of schoolmasters, not excluding Dr. Baker himself, would be satisfied with an "Advanced Course" which ended with the end of the school year in which the age of eighteen was reached.

Mr. A. T. Simmons showed the further difficulties which arise when the school course ends at sixteen. Too often electricity and magnetism are left out, so far as the majority of the boys are concerred - a serious matter. We may point cut that this means not merely the loss of a study of fascinating interest to most boys, but the further result is that school-work and the life of the world remain divorced. Mr. Simmons did another service to the discussion by indicating things which could be left out with advantage; we suggest that one of the most necessary things to do at present is to scrap useless topics of the Nicholson hydrometer type.

If we take a longer view, it is obvious that for future progress the training of teachers of physics is of first-rate importance, and the remarks of Prof. T. P. Nunn will be read with interest. The two main theses were (I) the need for the teacher to have studied his subject critically, (2) the benefit which results from a sound apprenticeship to the teacher's art. We agree that "the way of wisdom with regard to training colleges is not to suppress or to ignore them, but to take serious pains to strengthen them for the better performance of their indispensable duties." In our opinion, the training of science teachers is one of the vitally important items of educational reconstruction, and this might well be impressed upon local education authorities during the coming year. The need for "refresher courses", for teachers who have been at work for several years, possibly in a remote school, has been recognised by the more progressive authorities; but such courses rarely include physics or chemistry. Mr. J. Nichol was only too well justified in directing attention to the financial difficulty of the science master who wishes to keep up to date (this applies especially to those whose school is 